\title{
Isolation and Characterization of Nodule Associated Bacteria from Chickpea and their Potential for Plant Growth Promotion
}

\author{
Deepak Kumar Koli* and Karivaradharajan Swarnalakshmi
}

\author{
Division of Microbiology, ICAR-Indian Agricultural Research Institute (IARI), \\ New Delhi 110012, India \\ *Corresponding author:
}

\section{A B S T R A C T}

\section{Keywords}

Chickpea,

Endophytes,

Root nodules,

Growth promoting

traits, Rhizobium,

Nitrogen fixation,

16S rRNA

Article Info

Accepted:

19 April 2017

Available Online:

10 May 2017
A total of seventy three NAB were isolated from surface sterilized nodules of different chickpea (Cicer arietinum) cultivars grown in the field from IARI, New Delhi using various kinds of media. Screening for the improved seedling growth showed that $91.78 \%$ of them enhanced radical length, and $87.67 \%$ of them increased plumule length under invitro conditions. About twenty four isolates were selected from preliminary screening and were subjected to their growth promoting potential under pot culture conditions using selected cultivar (PUSA 372). The promising nodule associated bacteria (NAB 69) showed a significant increase in plant growth regarding shoot dry weight $(40.63 \%)$ and root dry weight $(45.09 \%)$ in comparison to control. Its interactive effect was evaluated with Mesorhizobium ciceri for growth attributes and nodulation potential under pot culture conditions. The highest nitrogenase activity $\left(74.12 \mu\right.$ moles $\mathrm{C}_{2} \mathrm{H}_{4} / \mathrm{g}$ of fresh weight of nodules/hr) was recorded in the treatment involving NAB 69 along with Mesorhizobium ciceri at 45 DAS (Vegetative stage). In-vitro screening for the functional potential of NAB showed a positive result with $\mathrm{P}$ solubilization. However, nitrogenase activity and siderophore production were not detected in the selected bacterial isolate. The 16S rDNA sequencing revealed that the bacterial isolate was closely related to Enterobacter sp. with $99 \%$ maximum identity. This investigation led to identifying the natural associations between the most promising nodule associated bacterium and Mesorhizobium ciceri in chickpea and the positive influence of their interactions.

\section{Introduction}

Chickpea (Cicer arietinum) is an important legume crop grown under rainfed agriculture in India. It's economic success relies on symbiotic nitrogen fixation (SNF) with root nodulating bacterium Mesorhizobium ciceri. These bacteria regularly interact with other rhizospheric microorganisms as well as host endophytic microorganisms. The endophytic bacteria reside latently or colonize the plant tissues actively without causing any apparent harm (Samish et al., 1963).
Endophytic bacteria, in addition to colonizing roots, shoots, leaves, seeds, and fruits, etc., these are also reported to colonize nodules of legume plants. The nodule endophytes have been isolated from alfalfa, clover, pea, bean, chickpea, soybean and lotus, etc. (Hung and Annapurna, 2004; Muresu et al., 2008; Dudeja et al., 2012), and a great diversity of these has been reported depending on the host genotypes and environmental conditions. The endophytic bacteria mainly belong to the 
members of Methylobacterium, Devosia, Blastobacter, Ochrobactrum, Shinella, Burkholderia, Cupriavidus, Bacillus, Pseudomonas and enterobacterial species (Li et al., 2008; Zhao et al., 2011). Some of these are known to stimulate plant growth, nitrogen fixation and also may induce of resistance to plant pathogens.

Endophytic symbiotic association between root nodulating Rhizobium and legumes is well documented where the microsymbiont fixes nitrogen in exchange of carbon from the host plant. Members of endosymbiotic Rhizobiaceae include the genera of Rhizobium, Bradyrhizobium, Sinorhizobium, Mesorhizobium, Azorhizobium and Allorhizobium, which nodulate different legume crops. Different plant species are reported to harbour endophytes in the range of $10^{3}-10^{6}$ CFU (Colony Forming Unit)/g tissue. The presence of endophytic bacteria depends on the plant genotype, plant age, tissue sampled, and also the season of isolation (Kuklinsky-Sobral et al., 2004). Further, nutrient availability, as well as soil type, may also determine their abundance and diversity. Non-rhizobial plant growth promoting endophytes such as Arthrobacter, Bacillus, Burkholderia, Dyella, Methylobacterium, Microbacterium, Staphylococcus, Streptomyces and Bacillus can also colonize nodules of a wide range of legumes (Tokala et al., 2002; Bai et al., 2002). Co-inoculation of Rhizobium with nodule endophytes improved plant growth, nodulation and yield in different legume crops (Sturz et al., 1997; Pandey et al., 2005; Rajendran et al., 2008). There is limited information available on the interactive effect between rhizobia and other Nodule associate bacteria $(\mathrm{NAB})$ on nodulation efficiency and associated crop response in chickpea. Therefore, the present study was focused to identify and characterize the nodule associated bacterium and its interaction with
Mesorhizobium for their functional role as well as growth and productivity of chickpea.

\section{Materials and Methods}

\section{Sampling procedure for chickpea crop}

Healthy and undamaged plant samples of different chickpea cultivars (BGD 72, PUSA 372, GNG 1581, PUSA 547, K 850, PUSA 256, ICC 5335, BGD 1005, SUBHRA) grown at IARI research field were uprooted at vegetative stages (45 DAS) of crop growth.

\section{Nodule associated bacteria in chickpea}

\section{Isolation and purification}

Nodule associated bacteria (nodule endophytes) were isolated from chickpea root nodules. Nodule tissues were surface sterilized using 4\% sodium hypochlorite $(\mathrm{NaOCl})$ for 4 min. followed by washing with sterile distilled water several times. It was then treated with $70 \%$ ethanol and washed at least five times with sterile distilled water (Gagne et al., 1987). Surface sterilized nodule tissue was then macerated in surface sterilized mortar and pestle and serially diluted using water blanks. After authenticating surface sterilization procedure, suitable dilutions (100 $\mu \mathrm{l})$ were spread plated on different media viz Yeast Extract Mannitol Agar (YEMA), Trypticase Soy Agar (TSA), Pikovskaya Medium, Nutrient Agar, Kings B Medium, R2A Agar and Jensen's Medium. The plates were incubated at $28 \pm 2^{\circ} \mathrm{C}$ for $24 \mathrm{hr}$ and the isolates were purified by quadrant streaking on respective growth medium.

\section{Growth and maintenance}

Single and purified nodule associated bacterial colony was grown on nutrient agar medium. The working cultures were grown on nutrient agar slants and maintained at $4^{\circ} \mathrm{C}$. 
Sub culturing was done as and when required. Stock culture of each isolate was also maintained as $15 \%$ glycerol stock at $-20^{\circ} \mathrm{C}$. The isolates were named as NAB and suffixed with arabic numeral to specify the isolate number.

\section{Preliminary screening of nodule associated bacteria by seed bioassay under in-vitro conditions and experimental observations}

Preliminary screening of nodule associated bacterial isolates for the growth of chickpea was performed by seed bioassay. Healthy chickpea seeds (cultivar PUSA 372) were sterilized by treating with $70 \%$ ethanol for 30 s, followed by $0.1 \%$ mercuric chloride for 3 min and then rinsing several times with sterile distilled water. Seed inoculation was performed by soaking surface sterilized seeds in bacterial suspension from exponential growth stage for $30 \mathrm{~min}$. These inoculated seeds were transferred to $0.8 \%$ water agar plates, incubated at $24 \pm 2{ }^{\circ} \mathrm{C}$ for 4 days and observed for seedling growth. Uninoculated control was also maintained. Observations on radical and plumule length, as well as germination percentage were measured and compared with appropriate control. The percent germination (\%) was calculated by dividing number of seed germinated to the total number of seeds sown. Seedling growth (cm) was measured in terms of radical and plumule length per germinated seed and average was calculated. Promising endophytes were selected for further screening. The selected bacterial isolates from preliminary screening were further reconfirmed by seed bioassay.

\section{Secondary screening of nodule associated bacteria for growth of chickpea under pot culture conditions}

About twenty four selected bacterial isolates screened after seed bioassays were assessed for their influence on the growth of chickpea plants under pot culture conditions. Pots of size 4" were filled with $2.5 \mathrm{~kg}$ of soil taken from IARI fields. Surface sterilized chickpea seeds (PUSA 372) were subjected to seed bacterization. A total of twenty five treatments with the completely randomized design were replicated three times, and three treated seeds were sown at $5 \mathrm{~cm}$ depth with equal spacing. Seeds without bacterial inoculation were used as the controls. Plants were harvested after 45 days and observations were scored on nodule numbers, root and shoot dry weight per plant. Root and shoot samples were dried in an oven at $60^{\circ} \mathrm{C}$ till constant weight was achieved and each treatment, average root and shoot dry weight was calculated and expressed as mg per plant. The best isolate in terms of its influence on plant parameters was selected for further study.

\section{Characterization of most promising bacterial isolate for plant growth promoting traits}

Broth culture of the selected bacterial isolate was grown in nutrient broth with titer value of $10^{6} \mathrm{cfu} / \mathrm{mL}$. The isolate was screened for its functional attributes such as nitrogenase activity as Acetylene Reduction Assay (ARA), P solubilization, IAA production, HCN production and siderophore production.

\section{Nitrogenase activity}

The promising bacterial isolate was characterized for nitrogenase activity by the method of Hardy et al., (1973) using $\mathrm{N}$-free Jensen's medium. Bacterial culture aliquots containing approximately $10^{5}-10^{6}$ cells were streaked on the slants of Jenson's medium and incubated at $28^{\circ} \mathrm{C}$ for 5-7 days. Following the incubation, the tubes were sealed with sterile suba seals. Ten percent of air space (v/v) was replaced with acetylene gas and tunes were then incubated for $24 \mathrm{hrs}$. Appropriate control was also maintained under similar conditions. One $\mathrm{mL}$ of air sample was injected into 
preheated gas chromatograph (Nucon 5765 model) housing Porapak $\mathrm{N}$ column with Flame Ionization Detector (FID). The column temperature was maintained at $100^{\circ} \mathrm{C}$ whereas injector and detector temperature were maintained at $110^{\circ} \mathrm{C}$. The peak area of standard ethylene was used for calculation and activity was expressed in terms of $\mu$ moles of $\mathrm{C}_{2} \mathrm{H}_{4} / \mathrm{mg}$ protein / $\mathrm{hr}$ as per equation.

$\mathrm{C} \times \mathrm{Ps} \times \mathrm{As} \times \mathrm{V}$

$\mathrm{P}_{\mathrm{STD}} \times \mathrm{A}_{\mathrm{STD}} \times \mathrm{T} \times \mathrm{P}$

Where, $\mathrm{C}=$ Concentration ( $\mu$ moles) of standard ethylene, $\mathrm{P}_{S}=$ Peak area of the sample, $A_{S}=$ Attenuation used for sample, $V=$ Volume of air space in the test tube, $\mathrm{P}_{\mathrm{STD}}=$ Peak area of standard ethylene, $\mathrm{A}_{\mathrm{STD}}=$ Attenuation used for standard ethylene, $\mathrm{T}=$ Incubation time (hours), $\mathrm{P}=$ Protein content $(\mathrm{mg} / \mathrm{mL})$

\section{Phosphate solubilization ability}

Selected endophyte was characterized for its ability to solubilize phosphate which was detected by using NBRIP medium developed by Nautiyal (1999). The medium was autoclaved, poured in plates and grids were prepared on Petri plates. To each grid, $8 \mu$ of bacterial culture $\left(10^{4} \mathrm{CFU}\right)$ was spotted. After spot inoculation, plates were incubated at $28 \pm 2^{\circ} \mathrm{C}$ for 6 days and observed for the development of P-solubilization zone around the colony.

\section{Siderophore production}

Siderophore production by selected bacterial isolate was detected by using Chrome azurol$\mathrm{S}$ assay (CAS) developed by Schwyn and Neilands (1987). The plates were prepared by mixing $100 \mathrm{~mL}$ CAS mixture with $300 \mathrm{~mL}$ nutrient agar medium. Selected bacterial culture $(10 \mu \mathrm{L})$ containing at least $10^{4}$ bacterial cells was spotted on CAS plate and incubated at $28 \pm 2^{\circ} \mathrm{C}$ for 7 days. The colony surrounded with deep yellow to orange colour was a positive indication of siderophore production.

\section{Interactive effect of most promising} bacterial isolate with Mesorhizobium ciceri

The interactive effect of most promising nodule associated bacteria and Mesorhizobium ciceri was studied on nodulation potential, growth attributes and nutrient uptake in chickpea variety PUSA 372 under pot culture conditions. Physio-chemical properties were analyzed in the soil used in the pots as per standard protocols. Surface sterilized seeds of chickpea were inoculated with exponentially grown bacterial culture for 30 min to have approximately $10^{6}$ cells per seed. Pots of 4" size were filled with $3 \mathrm{~kg}$ of soil and three seeds were sown in each pot containing field soils. The treatment details of the pot experiment are as follow- $\mathrm{T}_{1}$ Absolute control (No fertilizer, No Inoculation), $\mathrm{T}_{2}$ - Mesorhizobium ciceri alone, $\mathrm{T}_{3}$ - NAB alone, $\mathrm{T}_{4}$ - Mesorhizobium ciceri $+\mathrm{NAB}, \mathrm{T}_{5}-50 \%$ Recommended dose of fertilizer (RDF), $\mathrm{T}_{6}-$ Mesorhizobium $+50 \%$ $\mathrm{RDF}, \mathrm{T}_{7}-\mathrm{NAB}+50 \% \mathrm{RDF}, \mathrm{T}_{8}-$ Mesorhizobium ciceri $+\mathrm{NAB}+50 \% \mathrm{RDF}, \mathrm{T}_{9}-$ $100 \%$ RDF (positive control).

Mesorhizobium ciceri available in the Division of Microbiology was used in this study and Di-ammonium phosphate (DAP) @ $100 \mathrm{~kg} / \mathrm{ha}$ was used in RDF treatment. The plants were carefully uprooted after 45 DAS and observations were recorded on dry matter accumulation, nodulation, nitrogenase activity and $\mathrm{N}$ and $\mathrm{P}$ uptake.

\section{Nitrogenase activity as Acetylene Reducing Activity (ARA) in chickpea root nodules}

Plants were uprooted carefully and adhering soil was removed from roots carefully. Root nodules after recording fresh weight were 
transferred into assay vials and sealed with Suba seal. In each vial, $10 \%$ of air was replaced with equal volume of acetylene gas and incubated at $28 \pm 2^{\circ} \mathrm{C}$ for one hr. ARA activity was determined as described in the earlier section. Nitrogenase activity was determined by Acetylene Reducing Assay and expressed as $\mu$ moles of $\mathrm{C}_{2} \mathrm{H}_{4} / \mathrm{g}$ nodule fresh weight/hr.

\section{Dry matter accumulation}

Root and shoot samples were dried in an oven at $60^{\circ} \mathrm{C}$ till constant weight and biomass was calculated as mg dry weight per plant.

\section{Nodulation potential}

Nodules were detached from the roots and nodule number per plant as well as their fresh weight (mg) was recorded. These parameters were expressed on per plant basis.

Identification of promising nodule associated bacteria using $16 \mathrm{~S}$ rRNA partial gene sequencing

\section{Isolation of genomic DNA and 16S rRNA gene amplification}

Molecular identification of promising bacterial isolate was undertaken by $16 \mathrm{~S}$ rRNA gene amplification followed by sequencing. The selected bacterial isolate was grown in LB broth and incubated under optimal conditions. The genomic DNA was extracted using Sigma GenElute Bacterial genomic DNA kits, USA. The PCR reaction was performed by selective amplification of $16 \mathrm{~S}$ rRNA gene using equimolar concentrations of both forward primer - fD11 and reverse primer - rP2 (Weisburg et al., 1991). PCR master mix containing Taq DNA polymerase, dNTPs, Tris- $\mathrm{HCl}, \quad \mathrm{MgCl}_{2}$ stabilizer and tracking dye was used according to the manufacturer's instructions (GE healthcare
Life Sciences). The PCR reaction conditions used were $1 \mathrm{~min}$ at $94^{\circ} \mathrm{C}, 1 \mathrm{~min}$ at $55^{\circ} \mathrm{C}$ followed by $2 \mathrm{~min}$ at $72^{\circ} \mathrm{C}$ for 30 cycles. The amplicon size of $1.4 \mathrm{~kb}$ was recovered from agarose gel using a gel extraction kit (Sigma Life Science GenElute gel extraction kit, USA).

\section{Sequence analysis}

The purified PCR product was subjected to sequence analysis by Central Instrumentation Facility (CIF), Biotech Centre, Delhi University (South Campus), New Delhi and the nucleotide sequence of the amplified product was determined using same set of primers used for PCR amplification. The analysis of sequence was undertaken using Cap 3 software available online. Bacterial isolate was identified by comparative matching of the 16S rRNA gene sequence with homologus sequence using NCBI BLAST search tool (http://blast.ncbi.nlm.nih.gov/).

\section{Statistical analysis}

SPSS 16.0 statistical software was used for all quantitative data analysis including standard errors, critical difference, and analysis of variance (ANOVA).

\section{Results and Discussion}

\section{Isolation and purification of nodule associated bacteria from Chickpea cultivars}

Different cultivars (BGD 72, PUSA 372, GNG 1581, PUSA 547, K 850, PUSA 256, ICC 5335, BGD 1005, SUBHRA) of chickpea grown at ICAR-IARI, New Delhi research field were used for isolation of Nodule Associated Bacteria (NAB) or endophytes. The plants were uprooted at vegetative stages (45 DAS) and nodules were used for isolation 
of bacteria. A total of 73 endophytes showing different colony morphology were isolated using different media as discussed in material and method and bacterial isolates were selected on the basis of morphological parameters viz. size, shape, margin, colour, appearance and texture. Amongst the various media employed, Jensen's Medium showed highest number (19 morphotypes) of bacterial isolates followed by Yeast Extract Mannitol Agar (17 morphotypes), followed by Pikovskaya Medium and R2A Agar Medium (10 morphotypes each). Nine different morphotypes were also isolated on Trypticase Soy Agar. Minimum endophytic diversity was depicted by King's B Medium and Nutrient Agar Medium showing five and three different morphotypes respectively.

Out of the eleven different chickpea cultivars used, highest number (20 types) of morphotypes for nodule associated bacteria were obtained from cultivar BGD 72 followed by GNG 1581 which gave 13 types. In other cultivars, nine different morphotypes were isolated from PUSA 547 and PUSA 372, eight from PUSA 256 and five were obtained from $\mathrm{K}$ 850. The chickpea cultivars BGD 1005 and SUBHRA yielded four differents types of nodule associate bacteria, and only one morphotype was obtained from cultivar ICC 5335. It is indicating that genotype mediated variation in endophytic colonization and the benefits conferred by endophytes can be cultivar specific (Pillay and Nowak 1997; Conn et al., 1997; Bensalim et al., 1998).

In addition to microsymbiont, chickpea nodules harbour non-rhizobial endophytic microorganisms, and different cultivars of the same host are normally associated with a diverse range of endophytic microorganisms (Strobel and Daisy, 2003). Endophytic bacteria have been isolated from flowers, fruits, leaves, stems, roots and seeds of various plant species (Kobayashi and Palumbo, 2000) and their population have been reported in the range of $10^{2}-10^{4} \mathrm{cfu} \mathrm{g}^{-1}$ tissue (Kobayashi and Palumbo, 2000).

\section{Preliminary screening of nodule associated bacteria by seed bioassay under in-vitro conditions}

Preliminary screening of nodule associated bacteria was undertaken for improved seedling growth of chickpea (cultivar PUSA 372) using water agar plates. A total of 73 bacterial isolates were used for seed bioassay. These bacterial isolates improved the seed germination and seedling growth significantly. In all the treatments, $100 \%$ seed germination was observed.

A total of $91.78 \%$ bacterial isolates showed increase in radical length as compared to uninoculated control treatment and six isolates showed negative effect on radical length promotion when compared to control. Seven isolates viz NAB 15, NAB 20, NAB 60, NAB 62, NAB 63, NAB 64, and NAB 69 improved chickpea radical length in the range of $60-75 \%$ increase over control. This range was followed by six isolates namely NAB 19 , NAB 65, NAB 66, NAB 71, NAB 72 and NAB 73 which showed an increase of $45-60 \%$ over control whereas twenty two isolates showed $15-45 \%$ increase and the remaining showed less than $15 \%$ increase over control (Fig. 1). Endophytes isolated from diverse crops are known to produce different growth promoters as well as improve plant growth (Khan and Doty, 2009; Sgroy et al., 2009; Camerini et al., 2008; Panchal and Ingle, 2011; Zhao et al., 2011).

Bioassay screening also showed improved plumule length of germinated seeds with inoculation of nodule associated bacteria. Out of the total, selected isolates of $83.56 \%$ showed a positive effect on increased plumule 
length and twelve isolates showed reduced effect in comparison to control. Highest increase $(63.04 \%$ over control) of plumule length with NAB 64 was observed followed by NAB 62 where as seven isolates showed a percent enhancement in the range of 45-60\%; on the other hand, six exhibited an enhancement in the range of $30-45 \%$ and remaining isolates showed an enhancement which was less than $30 \%$ over control. On the basis of this, $24 \mathrm{NAB}$ were selected for further screening using plant bioassay (Fig. 2).

Secondary screening of nodule associated bacteria for growth of chickpea under pot culture conditions

The plant growth promoting efficiency of selected (total 24 isolates) bacterial isolates from in-vitro screening was assessed in chickpea, cultivar PUSA 372 under pot culture conditions.

Highest shoot dry weight increase $(40.63 \%$ over control) was observed when seeds were inoculated with NAB 69 followed by an enhancement of $39.58 \%$ with NAB 37 . Out of the total, $41.66 \%$ isolates showed a significant increase in the range of $30-50 \%$ in shoot dry weight and only one strain, NAB 55 exhibited the lowest increase of $5.21 \%$ in shoot dry weight (Fig 3). Endophytic and rhizospheric bacteria are known to play an important role in plant yield and growth promotion, plant health, and protection (Hallmann and Berg, 2006; Ryan et al., 2008; Saini et al., 2015).

There was also a significant improvement in root dry weight with inoculation of nodule associated bacteria and all isolates depicted positive effect. About 29.16\% of selected endophytes improved root weight in the range of $40-60 \%$ over control where as NAB 14 and NAB 53 showed only $13.39 \%$ increase. Out of all the isolates tested, NAB 69 showed fivefold increase in shoot dry weight which was $40.63 \%$ over control as well as threefold increase $(45.09 \%$ increase over control) in root dry weight as compared to control. About $37.50 \%$ of isolates were observed to increase total plant weight in the range of $30-50 \%$ (Fig $3)$. Therefore, on the basis of secondary screening, this particular isolate, i.e, NAB 69 was selected and tested for its functional plant growth promoting (PGP) traits as well as its interactive effect with Mesorhizobium ciceri.

\section{Characterization of most promising bacterial isolate for plant growth promoting traits}

The studies related to plant growth promoting traits in the selected bacterial isolate NAB 69 showed no nitrogenase activity and $P$ solubilizing potential was moderate. The selected bacterial isolate did not show siderophore production. Endophytic and rhizospheric bacteria are known to play an important role in plant yield and growth promotion, plant health, and protection (Hallmann and Berg, 2006; Ryan et al., 2008; Saini et al., 2015). The selected endophytic bacteria produced IAA at a low level (1 ppm) and showed a positive result for $P$ solubilization which was in congruence with the report of Li et al., (2008).

Interactive effect of most promising bacterial isolate with Mesorhizobium ciceri

The interaction effect of NAB and Mesorhizobium ciceri was evaluated on dry matter accumulation, nodulation potential, nitrogenase activity and $\mathrm{N}$ and $\mathrm{P}$ uptake. Physico-chemical properties of soil used in the experiment were organic carbon $0.42 \%$; available nitrogen $66.8 \mathrm{~kg} / \mathrm{ha}$; $\mathrm{pH}$ of 7.8 and $\mathrm{EC}$ of $0.38 \mathrm{mS} / \mathrm{cm}$.

\section{Dry matter accumulation}

The percent increase in root dry weight varied from 24.33 to $63.45 \%$ over uninoculated 
control. All the treatments showed positive effect on root biomass and the treatment $\mathrm{T}_{2}$ with Mesorhizobium alone improved root growth (63.45\% over control) followed by the treatments $\mathrm{T}_{7}, \mathrm{~T}_{9}$ and $\mathrm{T}_{6}$. The treatment with $50 \%$ RDF alone showed minimum increase $(24.33 \%)$. Similarly, all the treatments showed enhanced shoot growth when compared to absolute control $\left(\mathrm{T}_{1}\right)$. Highest increase in shoot dry weight $(76.87 \%)$ was observed in treatment $\mathrm{T}_{8}$ (Mesorhizobium $+\mathrm{NAB}+75 \% \mathrm{RDF}$ ) followed by treatments $\mathrm{T}_{9}(100 \% \quad \mathrm{RDF})$ and $\mathrm{T}_{7}$ $(\mathrm{NAB}+50 \%$ RDF). The lowest percent increase over control in the shoot biomass was observed in $\mathrm{T}_{2}(14.02 \%)$ and $\mathrm{T}_{3}$ (19.21\%). The treatment with Mesorhizobium ciceri along with NAB $\left(\mathrm{T}_{4}\right)$ showed $65.71 \%$ increase over uninoculated control. All the treatments increases total plant dry weight in the range of $20-70 \%$ over absolute control. The highest increase in total plant dry weight was shown by treatment $\mathrm{T}_{9} \quad(67.21 \%)$ followed by treatment $\mathrm{T}_{8} \quad(65.21 \%), \mathrm{T}_{7}$ $(64.61 \%)$ and $\mathrm{T}_{4}(61.01 \%)$ while the lowest increase was found in treatment $\mathrm{T}_{3}(22.80 \%)$ NAB alone (Fig. 4).

\section{Nodulation potential and nitrogenase activity}

Inoculation with NAB 69 increased nodule number/plant in comparison to control treatment $\left(\mathrm{T}_{1}\right)$. The percent increase over control was in the range of 30-75\%. Highest value was observed in treatment $\mathrm{T}_{4}(72.53 \%$ increase over control) followed by treatment $\mathrm{T}_{2}$ and $\mathrm{T}_{8}$. The treatment $\left(\mathrm{T}_{9}-100 \% \mathrm{RDF}\right)$ showed only 6.67 nodule number per plant which was less when compared to the treatments involving inoculation. Corresponding to nodule number, the nodule fresh weight also enhanced with inoculation in compare to control $\left(\mathrm{T}_{1}\right)$. All the treatments depicted improved nodule fresh weight in the range of 11-18 $\mathrm{mg}$ per plant. Treatment $\mathrm{T}_{4}$ (Mesorhizobium ciceri $+\mathrm{NAB}$ ) showed $63.64 \%$ increase over control followed by the treatment with Mesorhizobium alone. The Lowest percent increase over control (21.21\%) in terms of nodule fresh weight was observed in treatment with $100 \%$ RDF (Fig.5). These are in consistent with the reports on alfalfa in which co inoculation of non-rhizobial strain with Sinorhizobium meliloti also influenced nodulation, however, no significant effect of Sinorhizobium sp. alone was reported (Stajkovoic et al., 2009).

The nitrogenase activity was studies as Acetylene Reduction Assay (ARA) and was expressed in terms of $\mu$ moles of $\mathrm{C}_{2} \mathrm{H}_{4} / \mathrm{g}$ nodule fresh weight/ hr. The nodule ARA activity varied in the range of 11.64-74.12 umoles of $\mathrm{C}_{2} \mathrm{H}_{4} / \mathrm{g}$ nodule fresh weight/ $\mathrm{hr}$ under different treatments. The Highest ARA activity (74.12 $\mu$ moles of $\mathrm{C}_{2} \mathrm{H}_{4} / \mathrm{g}$ nodule fresh weight/ hr) was shown in treatment, $\mathrm{T}_{4}$ (NAB with Mesorhizobium ciceri) followed by the treatment $\mathrm{T}_{2}$ (Mesorhizobium alone) with the activity of $52.48 \mu$ moles of $\mathrm{C}_{2} \mathrm{H}_{4} / \mathrm{g}$ nodule fresh weight/ hr. The treatment, $\mathrm{T}_{8}$ (Mesorhizobium ciceri+NAB $+50 \%$ RDF) showed ARA activity of $49.55 \mu$ moles of $\mathrm{C}_{2} \mathrm{H}_{4} / \mathrm{g}$ nodule fresh weight/ hr. The Lowest ARA activity of $11.64 \mu$ moles of $\mathrm{C}_{2} \mathrm{H}_{4} / \mathrm{g}$ nodule fresh weight/hr was observed in $\mathrm{T}_{9}$ treatment $(100 \%$ RDF), positive control (Fig.5).

\section{Identification of most promising bacteria} based on 16S rRNA gene sequencing

The blast search results using 16S rRNA sequence results using NCBI data base for NAB 69 showed a maximum identity of $99 \%$ with Enterobacter sp. 
Fig.1 Influence of nodule associated bacteria on the chickpea growth promotion in terms of radical length (\% increase over control) using seed bioassay. Numbers in parentheses denote number of isolates

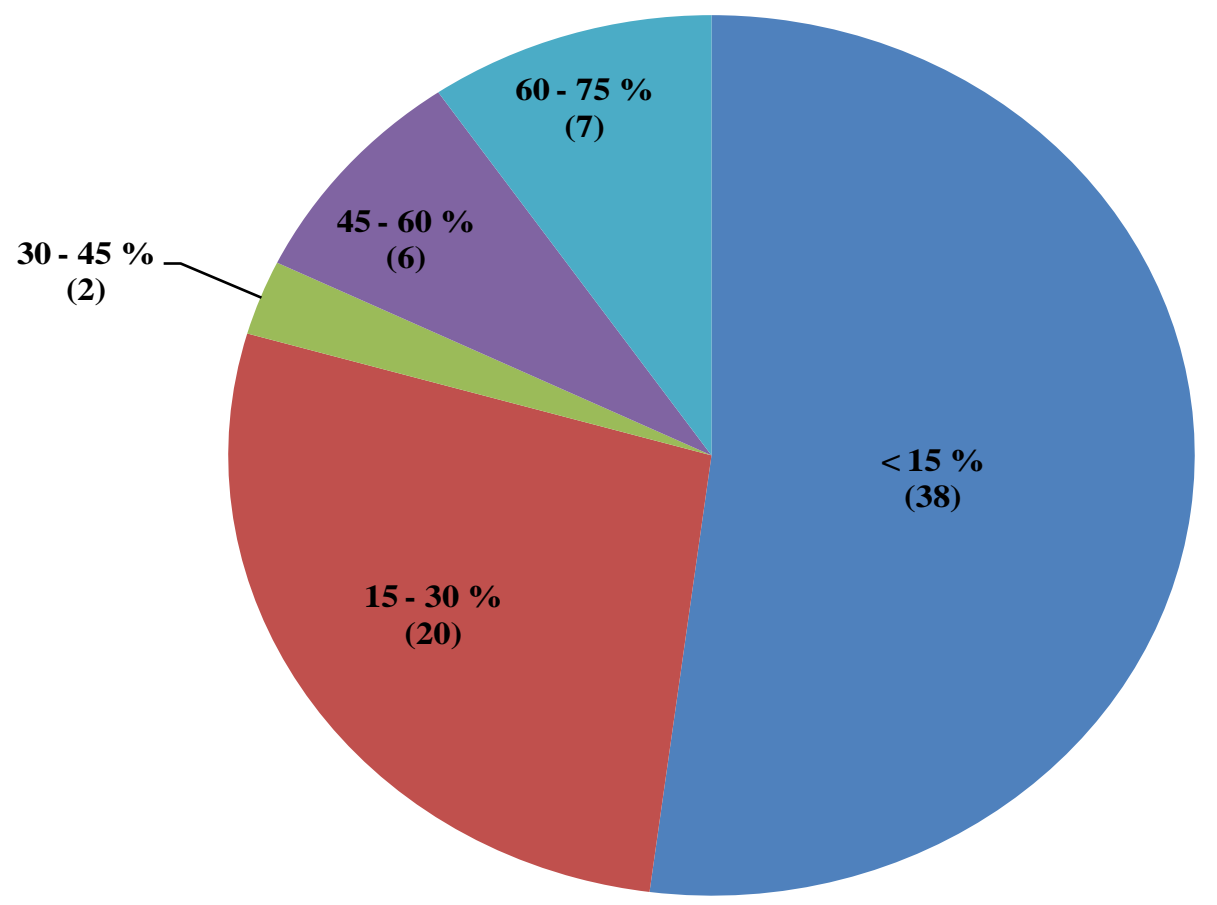

Fig.2 Changes in the plumule lengths of chickpea due to the inoculation with nodule associated bacteria (percent increase over control). Numbers in parentheses denote the number of isolates

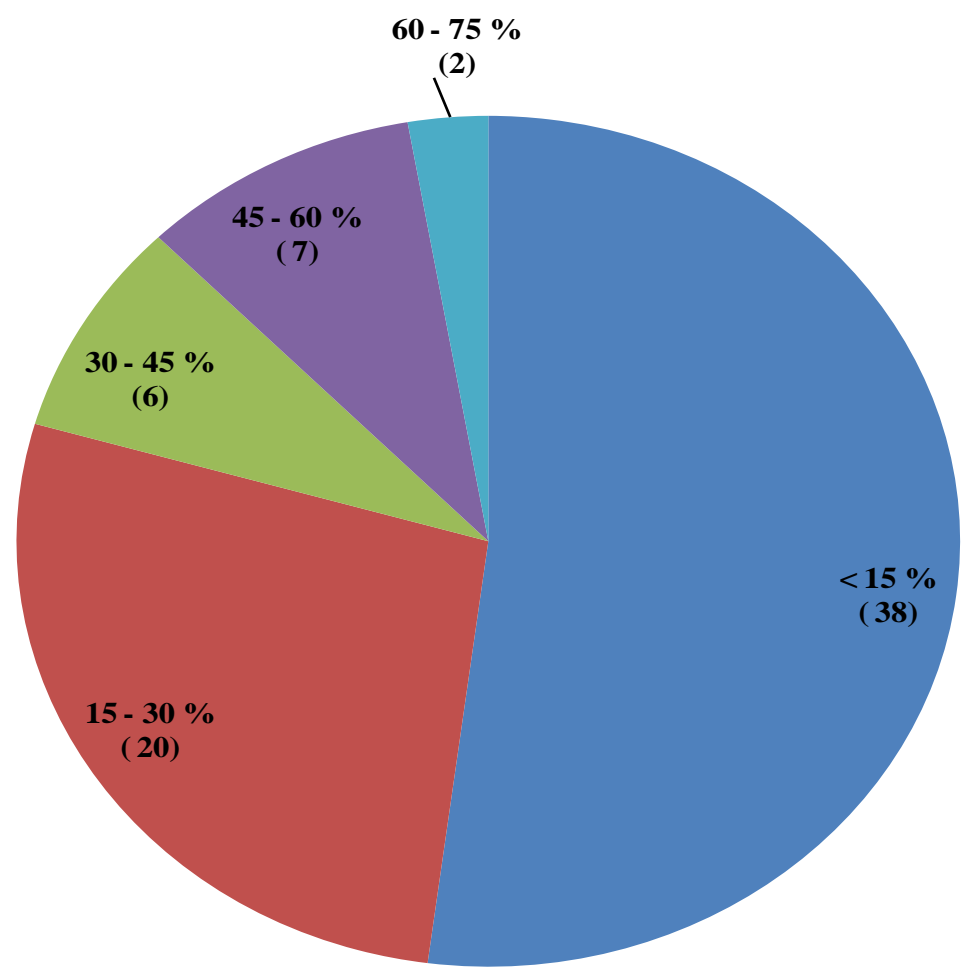


Fig.3 Influence of nodule associated bacteria (isolates numbered differently) on chickpea plant growth in pot experiment (Percent changes in shoot and root dry biomass relative to the control treatment are provided)

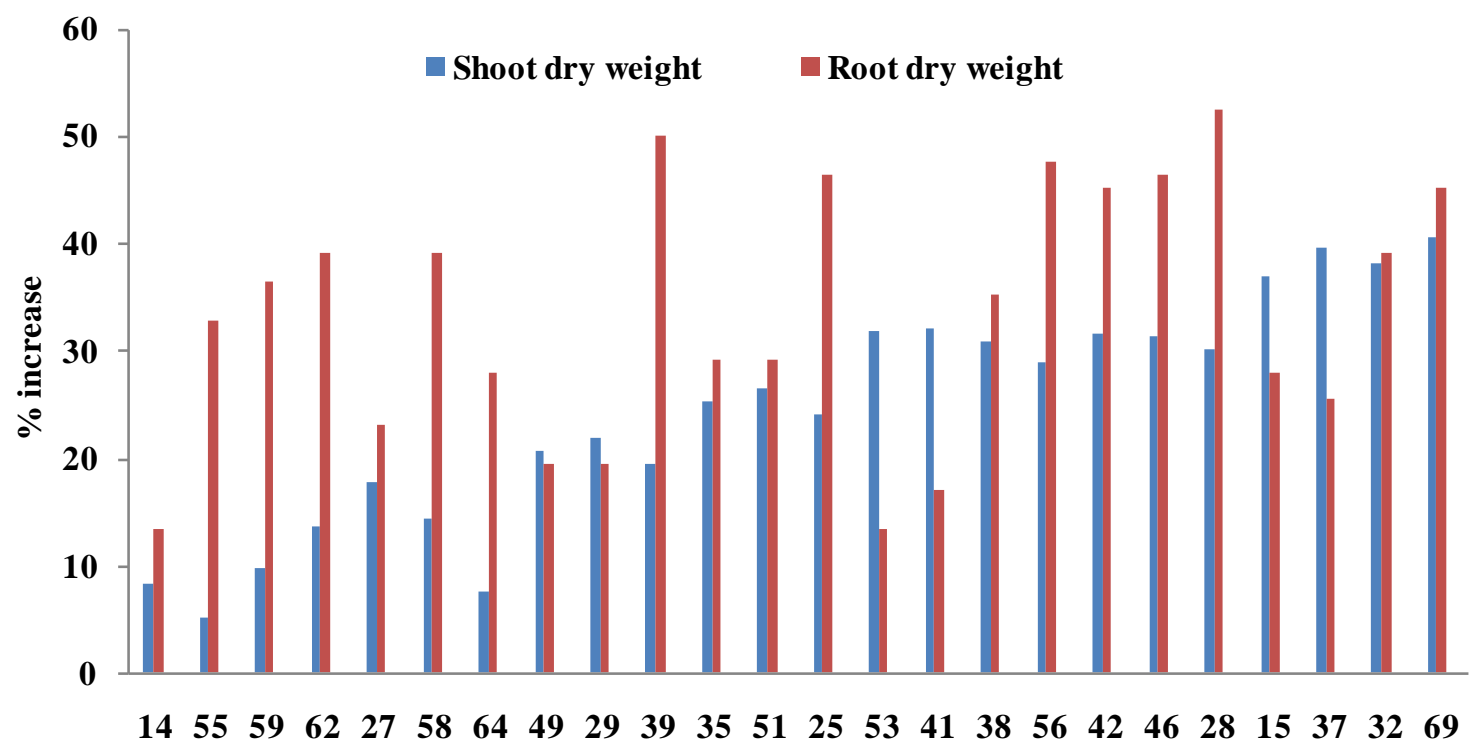

Nodule Associated Bacteria

Fig.4 Interactive effect of the promising nodule associated bacterium (NAB) and Mesorhizobium ciceri on chickpea growth

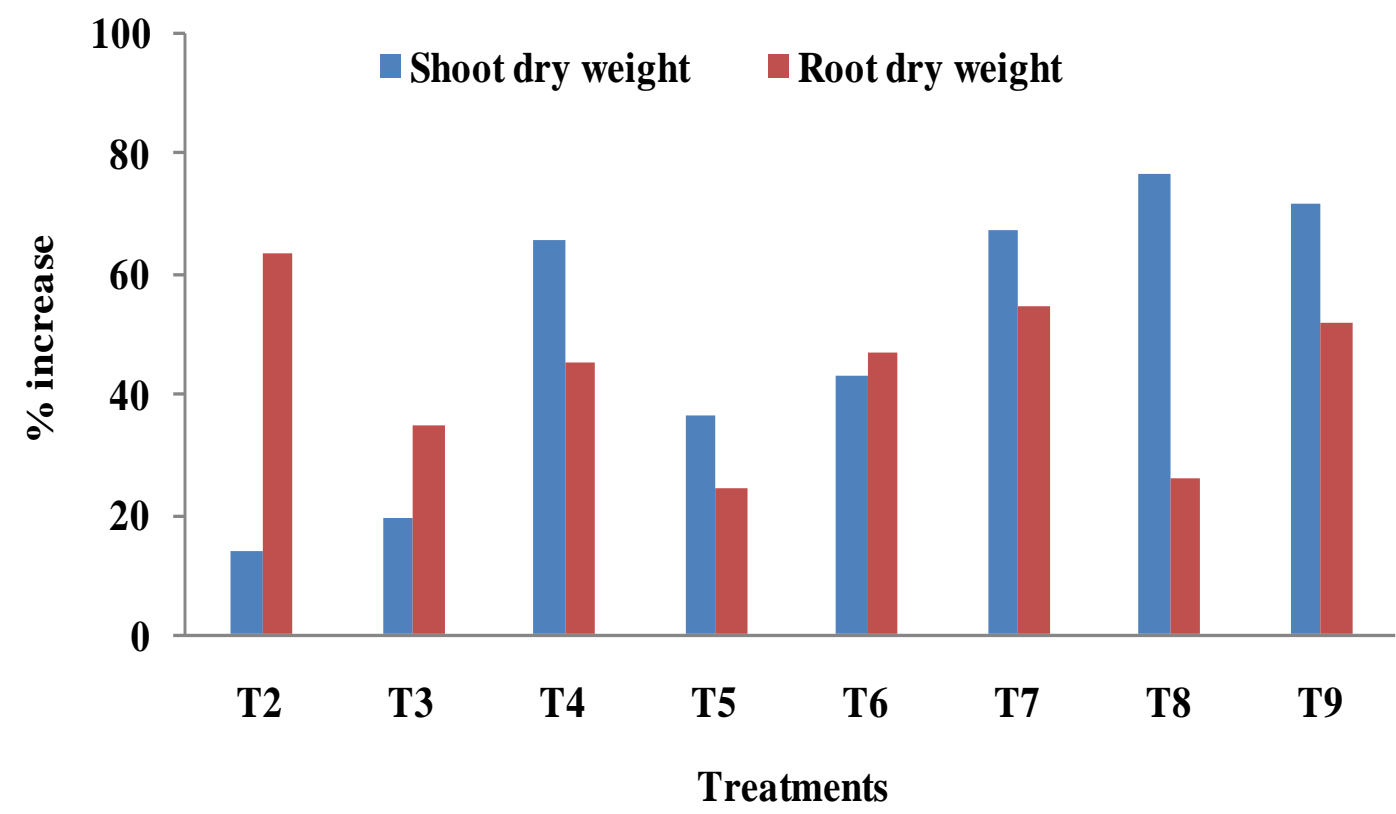

Percent increases or decreases over the control $\left(\mathrm{T}_{1}\right)$ are provided. Treatment details are: Treatment details are: $\mathrm{T}_{2}$-Mesorhizobium ciceri alone; $\mathrm{T}_{3}-\mathrm{NAB}$ alone; $\mathrm{T}_{4}-$ Mesorhizobium ciceri+NAB; $\mathrm{T}_{5}-50 \%$ RDF (positive control); $\mathrm{T}_{6}$-Mesorhizobium $+50 \%$ RDF; $\mathrm{T}_{7}-\mathrm{NAB}+50 \%$ RDF; $\mathrm{T}_{8}$-Mesorhizobium ciceri+NAB+50\% RDF \& $\mathrm{T}_{9}-100 \%$ RDF (positive control). 
Fig.5 Nodulation potential and nitrogenase activity in chickpea as influenced by the interactive effect of the promising nodule associated bacterium (NAB) and M. ciceri

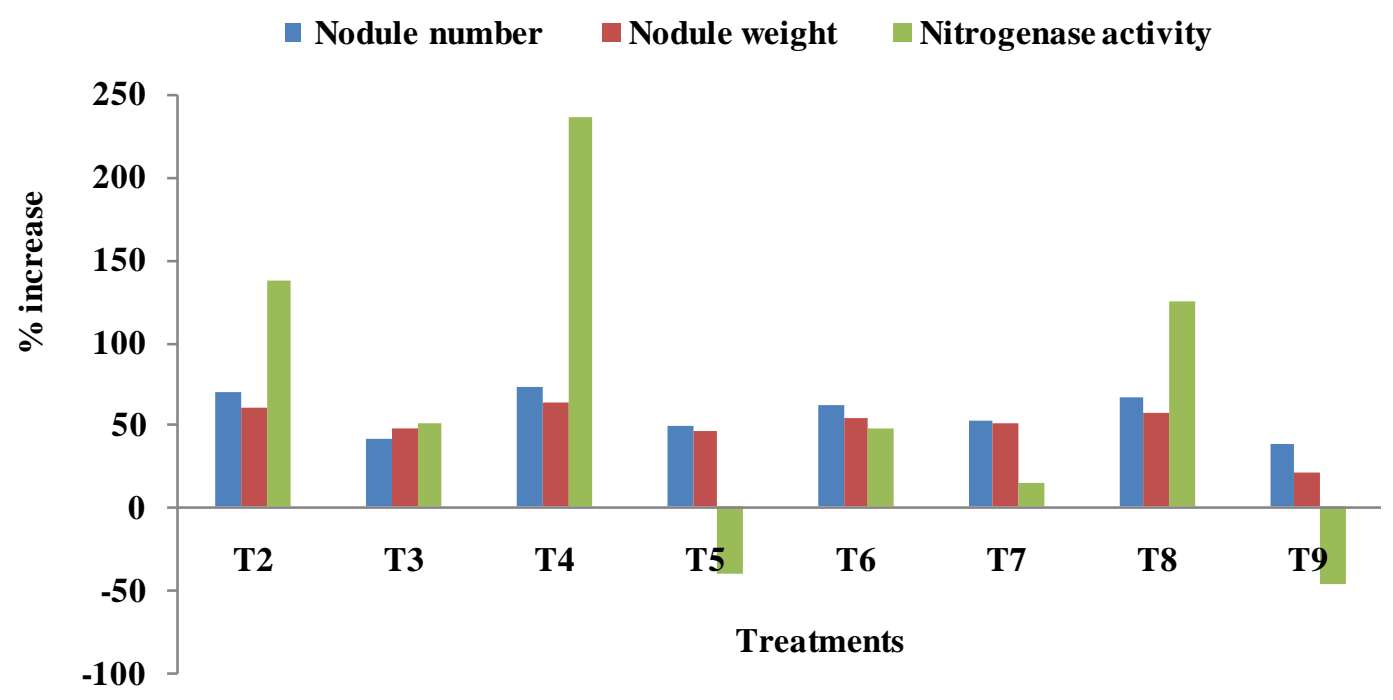

Percent increases or decreases over the control $\left(\mathrm{T}_{1}\right)$ are provided. Treatment details are: Treatment details are: $\mathrm{T}_{2}$-Mesorhizobium ciceri alone; $\mathrm{T}_{3}-\mathrm{NAB}$ alone; $\mathrm{T}_{4}-$ Mesorhizobium ciceri+NAB; $\mathrm{T}_{5}-50 \%$ RDF (positive control); $\mathrm{T}_{6}$-Mesorhizobium $+50 \%$ RDF; $\mathrm{T}_{7}-\mathrm{NAB}+50 \%$ RDF; $\mathrm{T}_{8}$-Mesorhizobium ciceri+NAB+50\% RDF \& $\mathrm{T}_{9}-100 \%$ RDF (positive control)

The plant growth promoting functions of Enterobacter sp. isolated from poplar host has been reported (Taghavi et al., 2010). However, systemic approach is required to understand its endophytic colonization, establishment as well as interaction with the plant (Taghavi et al., 2009).

\section{Acknowledgement}

The authors are gratefully acknowledge the advice and valuable suggestions provided by the Head, Professor and Advisory Committee members, Division of Microbiology and the Post Graduate School, ICAR- Indian Agricultural Research Institute, New Delhi.

\section{References}

Bai, Y., D'Aoust, F., Smith, D.L., and Driscoll, B.T. 2002. Isolation of plantgrowth-promoting Bacillus strains from soybean root nodules. Canadian $J$. Microbiol., 48(3): 230-238

Bensalim, S., Nowak, J., and Asiedu, S.K., 1998. A plant growth promoting rhizobacterium and temperature effects on performance of 18 clones of potato. American J. Potato Res., 75(3): 145-152.

Camerini, S., Senatore, B., Lonardo, E., Imperlini, E., Bianco, C., Moschetti, G., and Defez, R. 2008. Introduction of a novel pathway for IAA biosynthesis to rhizobia alters vetch root nodule development. Arch. Microbiol., 190(1): 67-77

Conn, K.L., Lazarovits, G., and Nowak, J. 1997 Agnotobiotic bioassay for studying interactions between potatoes and plant growth-promoting rhizobacteria. Canadian J. Microbiol., 43(9): 801-808.

Dudeja, S.S., Giri, R., Saini, R., Suneja-Madan, P., and Kothe, E. 2012. 
Interaction of endophytic microbes with legumes. J. Basic Microbiol., 52(3): 248-260.

Gagne, S., Richard, C., Rousseau, H., and Antoun,.H. 1987. Xylem-residing bacteria in alfalfa roots. Canadian $J$. Microbiol., 33(11): 996-1000.

Hallmann, J., and Berg, G. 2006. Spectrum and population dynamics of bacterial root endophytes. In: Schulz, Barbara JE, Boyle, Christine JC, Sieber and Thomas N (Eds), Microbial root endophytes Springer Berlin Heidelberg. pp. 15-31.

Hardy, R., Burns, R.C., and Holsten, R.D. 1973. Applications of the acetyleneethylene assay for measurement of nitrogen fixation. Soil Biol. Biochem., 5(1): 47-81.

Hung, P.Q., and Annapurna, K. 2004. Isolation and characterization of endophytic bacteria in soybean (Glycine sp.) Omonrice, 12: 92-101.

Khan, Z., and Doty, S.L. 2009. Characterization of bacterial endophytes of sweet potato plants. Plant and Soil, 322(1-2): 197-207.

Kobayashi, D.Y., and Palumbo, J.D. 2000. Bacterial endophytes and their effects on plants and uses in agriculture. Microbial Endophytes, 19: 199-233.

Kuklinsky-Sobral, J., Araújo, W.L., Mendes, R., Geraldi, I.O., Pizzirani-Kleiner, A.A., and Azevedo, J.L. 2004. Isolation and characterization of soybean-associated bacteria and their potential for plant growth promotion. Environ. Microbiol., 6(12): 1244-1251.

Li, J.H., Wang, E.T., Chen, W.F., and Chen, W.X. 2008. Genetic diversity and potential for promotion of plant growth detected in nodule endophytic bacteria of soybean grown in Heilongiiang province of China. Soil Biol. Biochem., 40(1): 238-246.
Muresu, R., Polone, E., Sulas, L., Baldan, B., Tondello, A., Delogu, G., Cappuccinelli, P., Alberghini, S., Benhizia, Y., Benhizia, H., Benguedouar, A., Mori, B., Calamassi, R., Dazzo, F.B., and Squartini, A. 2008. Coexistence of predominantly nonculturable rhizobia with diverse, endophytic bacterial taxa within nodules of wild legumes. FEMS Microbiol. Ecol., 63(3): 383-400

Nautiyal, C.S. 1999. An efficient microbiological growth medium for screening phosphate solubilizing microorganisms. FEMS Microbiol. Lett., 170(1): 265-270.

Panchal, H., and Ingle, S. 2011. Isolation and characterization of endophytes from the root of medicinal plant Chlorophytum borivilianum (Safed musli). J. Adv. Res. Develop., 2(2): 205-209.

Pandey, P., Kang, S.C., and Maheshwari, D.K. 2005. Isolation of endophytic plant growth promoting Burkholderia sp. MSSP from root nodules of Mimosa pudica. Curr. Sci., 86(1): 202-207.

Pillay, V.K., and Nowak, J. 1997. Inoculum density temperature and genotype effects on in-vitro growth promotion and epiphytic and endophytic colonization of tomato (Lycopersicon esculentum L.) seedlings inoculated with a pseudomonad bacterium. Canadian J. Microbiol., 43(4): 354-361.

Rajendran, G., Sing, F., Desai, A.J., and Archana, G. 2008. Enhanced growth and nodulation of pigeonpea by coinoculation of Bacillus strains with Rhizobium sp. Biores. Technol., 99(11): 4544-4550.

Ryan, R.P., Germaine, K., Franks, A., Ryan, D.J., and Dowling, D.N. 2008. Bacterial endophytes: recent developments and applications. FEMS Microbiol. Lett., 278(1): 1-9. 
Saini, R., Dudeja, S.S., Giri, R., and Kumar, V. 2015. Isolation characterization and evaluation of bacterial root and nodule endophytes from chickpea cultivated in Northern India. $J$ Basic Microbiol., 55(1): 74-81.

Samish, Z., Etinger-Tulczynska, R., and Bick, M. 1963. The microflora within the tissue of fruits and vegetables. J. Food Sci., 28(3): 259-266

Schwyn, B., and Neilands, J.B. 1987. Universal chemical assay for the detection and determination of siderophores. Anal. Biochem., 160(1): 47-56.

Sgroy, V., Cassan, F., Masciarelli, O., Del Papa, M.F., Lagares, A., and Luna, V. 2009. Isolation and characterization of endophytic plant growth-promoting (PGPB) or stress homeostasisregulating (PSHB) bacteria associated to the halophyte Prosopis strombulifera. Appl. Microbiol. and Biotechnol., 85(2): 371-381.

Stajković, O., De Meyer, S., Miličić, B., Willems, A., and Delić, D. 2009. Isolation and characterization of endophytic non-rhizobial bacteria from root nodules of alfalfa (Medicago sativa L.). Botanica Serbica, 33(1): 107-114.

Strobel, G., and Daisy, B. 2003. Bioprospecting for microbial endophytes and their natural products. Microbiol. Mol. Biol. Rev., 67(4): 491-502.

Sturz, A.V., Christie, B.R., Matheson, B.G., and Nowak, J. 1997. Biodiversity of endophytic bacteria which colonize red clover nodules roots stems and foliage and their influence on host growth. Biol. Fertility of Soils, 25(1): 13-19.

Taghavi, S., Garafola, C., Monchy, S., Newman, L., Hoffman, A., Weyens, N., Barac, T., Vangronsveld, J., and Lelie, D.V.D. 2009. Genome survey and characterization of endophytic bacteria exhibiting a beneficial effect on growth and development of poplar trees. Appl. Environ. Microbiol., 75(3): 748-757.

Taghavi, S., van der Lelie, D., Hoffman, A., Zhang, Y.B., Walla, M.D., Vangronsveld, J., Newman, L., and Monchy, S. 2010. Genome sequence of the plant growth promoting endophytic bacterium Enterobacter sp. 638. PLoS Genetics, 6(5): e1000943.

Tokala, R.K., Strap, J.L., Jung, C.M., Crawford, D.L., Salove, M.H., Deobald, L.A., and Morra, M.J. 2002. Novel plant-microbe rhizosphere interaction involving Streptomyces lydicus WYEC108 and the pea plant (Pisum sativum). Appl.

Environ. Microbiol., 68(5): 2161-2171.

Weisburg, W.G., Barns, S.M., Pelletier, D.A., and Lane, D.J. 1991. 16S ribosomal DNA amplification for phylogenetic study. J. Bacteriol., 173(2): 697-703.

Zhao, L., Xu, Y., Sun, R., Deng, Z., Yang, W., and Wei, G. 2011. Identification and characterization of the endophytic plant growth promoter Bacillus cereus strain MQ23 isolated from Sophora Alopecuroides root nodules. Brazilian J. Microbiol., 42(2): $567-575$

\section{How to cite this article:}

Deepak Kumar Koli and Karivaradharajan Swarnalakshmi. 2017. Isolation and Characterization of Nodule Associated Bacteria from Chickpea and their Potential for Plant Growth Promotion. Int.J.Curr.Microbiol.App.Sci. 6(5): 1992-2004. doi: https://doi.org/10.20546/ijcmas.2017.605.223 